\title{
Analysis of capacity community level in various potential disasters at dinoyo and sukun sub-district, Malang city
}

\author{
Mukhamad Fathoni ${ }^{*}$, Turniningtyas Ayu ${ }^{2}$, Fadly $\mathrm{Usman}^{2}$, Sunaryo ${ }^{2}$, Lestari Sumi $^{2}$, Ah Yusuf ${ }^{3}$, and Christrijogo \\ Sumartono $^{4}$ \\ ${ }^{1}$ Department of Nursing, Faculty of Medicine, Universitas Brawijaya, Malang and Ph.D. in Nursing student, Faculty of Nursing, \\ Airlangga University \\ ${ }^{2}$ Universitas Brawijaya \\ ${ }^{3}$ Faculty of Nursing, Airlangga University \\ ${ }^{4}$ Head of School Disaster, Airlangga University
}

\begin{abstract}
The natural disaster in pandemic covid-19 will still ongoing in East Java, Indonesia. Apart from the virus pandemic, there are still several potential disasters in that sub-district, namely floods and landslides. Many disasters have occurred resulting in the need for people living in the area to anticipate, especially if the three disasters occur simultaneously. In Malang, this case of sub-district apparatus and the BPBD Malang City has not been able to optimally help restore the condition of the community due to the complexity of conditions that occur in the field. Therefore, the community needs to know their capacity to be able to anticipate if it is two or three will happen. Capacity is a combination of all the forces that exist in a community, social or organizational group that can reduce the impact of disaster risk or impact (UN-ISDR, 2004). The capacity assessment in this study identifies the capitals owned by the community. These capitals include natural, human, physical, financial, and social capital. The five capitals will later be described in the pentagon assets so that it will be known which capacities in the capital are the strengths and weaknesses of the people of Dinoyo and Sukun sub-district
\end{abstract}

\section{Introduction}

Disasters can occur at any time in any part of the world with a dramatic impact on individuals, families, and communities, causing a threat to the quality of life (International Council of Nurse (ICN) \& World Health Organization (WHO), 2009). Disasters arise when a threat meets vulnerable people who have low or no capacity to respond to the threat. The combination of the two causes disruption of people's lives.

Disasters have a very big influence on humans and the surrounding environment such as mass death, disability, hunger, poverty, and infrastructure destruction (Mizam, 2012). According to Indonesian Disaster Data and Information, in 2016, there were 2,342 disasters, an increase of $35 \%$ when compared to the number of disasters in 2015 that occurred 1,582 disasters. If averaged out, it means that every day there are about five disasters that hit Indonesia. The geographical location of Malang City which is surrounded by Mount Semeru, Mount Arjuna, and Kawi makes this area also an earthquakeprone area. Meanwhile, the potential for flooding and landslides around the watershed is also large, seeing that the city of Malang is passed by four major rivers, namely the Brantas River, the Amprong River, the Metro River, and the Bango River. Disaster incidence data in Malang City in 2019 at least 217 incidents (data from PUSDALOPS BPBD Malang City) which can be categorized as disasters. The disaster occurred in five subdistricts which were grouped into several types, namely landslides, flooding / momentary inundation, tornadoes and the last one was the COVID-19 outbreak which is still ongoing today. The impact of the disaster can be seen directly from the damage and losses. Meanwhile, in the social aspect, it can be seen from the disruption of access, impaired function, and increased risk. The people affected by the disaster not only experienced the impact of physical damage to house buildings but also suffered social, economic, cultural, and psychological losses.

Floods and landslides have an impact on decreasing the quality of clean water; damaged social facilities such as meeting halls, road access, places of worship, schools; family sanitation so that the cost of fulfilling their daily needs will increase. Moreover, if treatment is not done immediately, there will be an increased risk such as an increase in disease outbreaks. Then in the economic sector, people's businesses suffer damage from both business premises, business products, and customers.

\footnotetext{
* Corresponding author: mfathony@ub.ac.id
} 
Loss of access to work for families will result in income losses.

To handle post-disaster and minimize the risk increase due to disasters, BPBD Malang City conducts PostDisaster Needs Assessment Activities. These activities include surveys of the social, economic, cultural, and psychological needs of the post-disaster community. Then the survey results will become material for a Focus Group Discussion (FGD) which will later be used as the basis for the preparation of the Post-Disaster Recovery Needs Assessment Results Document (Jitupasna).

\section{Method}

\subsection{Sampling Technique}

Sampling in this study using the purposive sampling technique. The purposive sampling technique is a purposive sampling technique. The sample is intended for respondents who will be given a questionnaire. Sampling will be addressed to all participants in Sukun and Dinoyo Villages who attend the meeting. The analytical tool used in determining the sample in each kelurahan is the Linear Time Function, which is an analysis based on the estimation of time constraints. This is used considering that it is still in the state of the COVID 19 pandemic, so space and time are limited. The formula is used as follows:

$$
n=\frac{T-t_{0}}{t_{i}}
$$

Note:

$\mathrm{n}=$ amount of minimum sample

$\mathrm{T}=$ avaliable time ( 24 days $\mathrm{x} 2$ hour/day $=48$ hour $)$

$t_{0}=$ time to take sample (12 days $\times 2$ hour/day $=24$ hour)

$t_{I}=$ time to need for people to filling quesioner $(0,25$ hour)

$$
\begin{gathered}
n=\frac{48-24}{0,25} \\
n=96 \text { sample }
\end{gathered}
$$

The sample required is 96 , with a proportion of 30 samples from the Dinoyo Sub-district and 66 samples from the Sukun Sub-district.

\subsection{Data Collection Technique}

Data collection is a standard for obtaining the required data. The data collection technique is in the form of primary data collection which is obtained from distributing questionnaires.

\subsection{Capacity Level Analysis}

The calculation capacity level of Sukun and Dinoyo Subdistrict people was carried out by distributing questionnaires according to the sample proportions. The questionnaire contains questions related to capacity indicators and the classification of each parameter to be assessed in Table 1.

Table 1 Indicators of Capacity Community $[1,4,6]$

\begin{tabular}{|l|l|}
\hline \multicolumn{1}{|c|}{ Capacity } & \multicolumn{1}{c|}{ Indicator } \\
\hline Natural Capital & 1. Average condition of water quality \\
\hline Social Capital & $\begin{array}{l}\text { 1. The average kinship between } \\
\text { neighbors } \\
\text { 2. Average public confidence in } \\
\text { circulating disaster information }\end{array}$ \\
\hline Human Capital & $\begin{array}{l}\text { 1. Average knowledge of signs of } \\
\text { disaster }\end{array}$ \\
\hline $\begin{array}{l}\text { Financial } \\
\text { Caperage people get education } \\
\text { disaster }\end{array}$ \\
\hline Physic Capital & $\begin{array}{l}\text { 1. Average people's income } \\
\text { 2. Average saving ownership }\end{array}$ \\
\hline
\end{tabular}

Before determining the level of capacity the data is processed first, because the unit of analysis desired is RW, while the data obtained is at the level of the head of the family (KK). Then it needs to be changed according to equation 2

Data for each subdistrict $=\frac{\sum \text { data } K K}{\text { amount of people }}$

Next, determine the level of capacity through the following steps:

1. The final score (equation 2) for each capital is converted to a value of 1,2 , and 3 for low, medium, and high

2. Calculate conversion result with equation 3 .

$$
\begin{gathered}
L_{\text {pentagon }}=\left(\frac{1}{2} a b \cdot \sin 72^{0}\right)+\left(\frac{1}{2} b c \cdot \sin 72^{0}\right)+ \\
\left(\frac{1}{2} c d \cdot \sin 72^{0}\right)+\left(\frac{1}{2} \text { de } \sin 72^{0}\right)+\left(\frac{1}{2} \text { ea } \sin 72^{0}\right)
\end{gathered}
$$

3. Do it with the other four capitals to get a complete pentagon image as shown in Fig 1

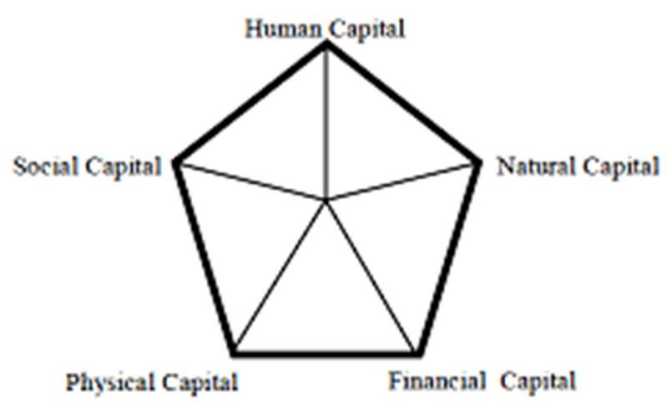

Fig 1 Pentagon Asset [4]

\section{Result and Discussion}

\subsection{Natural Capital}

The natural capital used in this study is the condition of drinking water quality. Drinking water is a basic need of urban communities. Good quality drinking water is a sign 
that the environment in the region is still preserved beautifully.

In Fig 2, it is known that the quality of drinking water in the two villages is quite good. The number of respondents who stated that it was quite good was 53 respondents. Good quality drinking water can be consumed by the community and indirectly affects public health. Consuming good drinking water will be able to increase the body's resilience in facing various disasters that have the potential to occur.

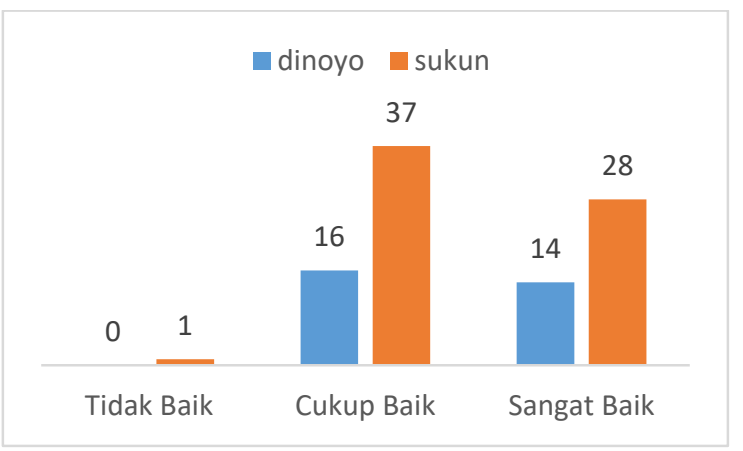

Fig 2 Water Quality

\subsection{Social Capital}

Factors that affect social capital in Dinoyo and breadfruit are a kinship between neighbors and the level of public confidence in the delivery of information. Kinship is seen based on how close the person is to the neighbor because the neighbor is the first person to help in the event of a disaster.

According to Fig 3, it is known that the average value for kinship is in the range of 2 to 3 . Number 2 means quite good and number 3 shows good information. So that the good kinship in Dinoyo and Sukun Kelurahan is pretty good to good.

Then on the factor of public trust in the disaster information presented, the people of Dinoyo and Sukun Subdistrict have an average score of 2 to 3 again. Score 2 means that information from the Subdistrict government is trusted, while score 3 means that news delivery that people trust comes from BPBD Malang City. Dinoyo Subdistrict is more likely to trust the information conveyed by BPBD, while Sukun Subdistrict has more trust in Subdistrict government.

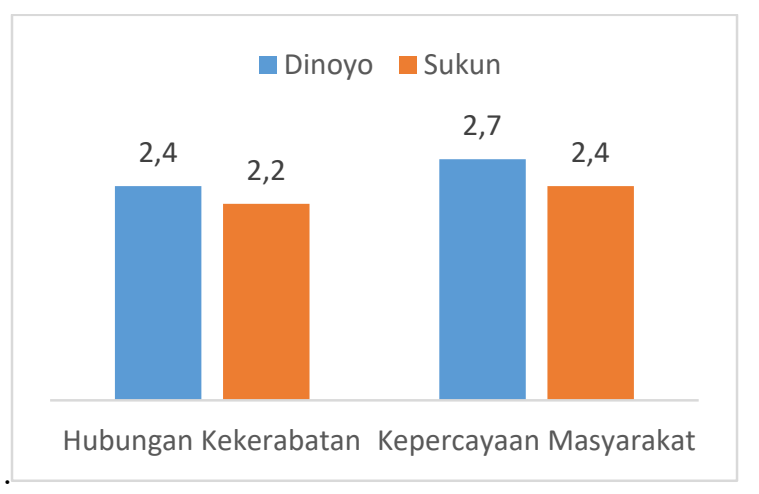

Fig 3 Kinship and Community Trust Relationship

\subsection{Human Capital}

Human capital is measured through the knowledge of respondents to be able to recognize signs of disasters, including floods, landslides, and the COVID-19 pandemic as well as participation in counseling on various disasters.

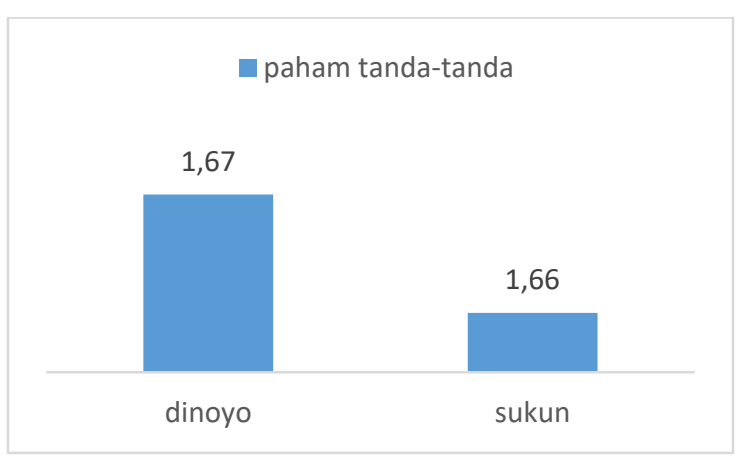

Fig 4 Public Understanding in Knowing the Signs of Disaster

Public understanding in knowing the signs of a disaster is still lacking. The value of this factor shows the number 1 . Understanding to be able to know the signs is very important for the community to be able to avoid the disaster that will occur.

Then in the extension participation component, the community of the two sub-districts has on average attended counseling. There are $90 \%$ of respondents in the Dinoyo Village who stated that they had attended counseling, while for the respondents in the Sukun Village it was $71 \%$. Respondents thought that the education related to this disaster was quite useful for them. In addition to increasing knowledge, it can also anticipate potential disasters that occur.

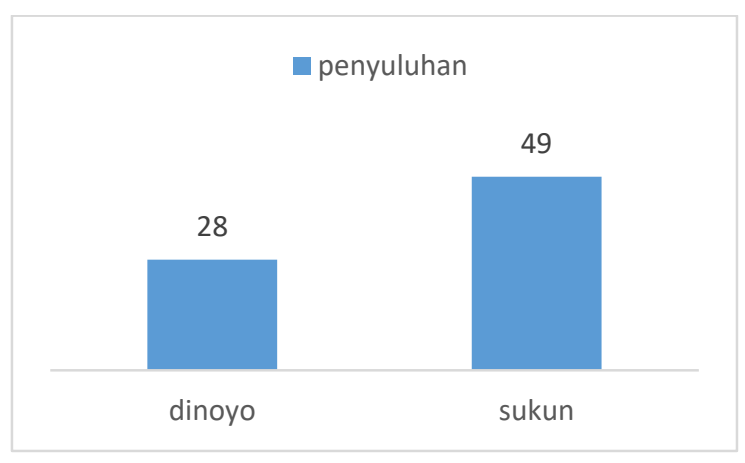

Fig 5 Community Attended Disaster Education

\subsection{Financial Capital}

Financial capital is the ability of the community to be able to recover from disasters, including floods, landslides, and COVID-19 pandemic, through their assets. The forms of these assets are in the form of income, ownership of savings, and assistance. Fig 6 shows the average income in the two subdistricts. The income of the people of the Sukun Subdistrict is greater than Dinoyo Subdistrict. The average income of Sukun residents is IDR 2,072,879, while in the Dinoyo community it is only IDR $1,774,333$. High income indicates that the community can survive in 
the event of a disaster because it can spend money on necessary needs.

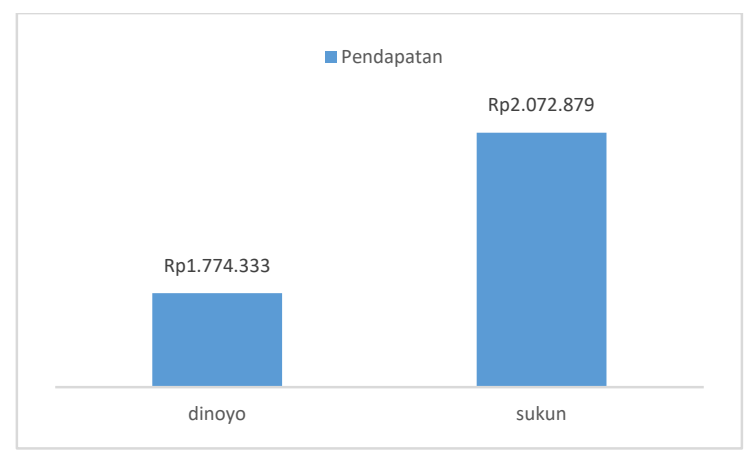

Fig 6 Average Income

Apart from income, factors affecting financial capital are ownership of savings and assistance. Fig 7 shows that the ownership of savings in the two urban villages is quite small if you look at the various types of financial institutions that are very large in Malang City. However, when compared to the Dinoyo people, $43 \%$ of respondents have savings. The amount of savings ranges from hundreds of thousands of rupiah. Ownership of savings for the community is very important to be able to survive in the current conditions. Because savings have liquidity, money can be withdrawn at any time.

Furthermore, in the aid component, the value of assistance received by respondents was still low. Only $45 \%$ of the respondents in the Sukun Subdistrict received assistance, while in Dinoyo Subdistrict it was even smaller. The funds disbursed by the central government to help the community during this pandemic were many and varied. Generally, people get assistance from the government, tough subdistricts, and banks. These assistance programs vary, some in the form of "Kartu Pra Kerja", "Bantuan Langsung Tunai (BLT)", Social Security and others. The form of assistance received was generally in the form of money, but there were also necessities.

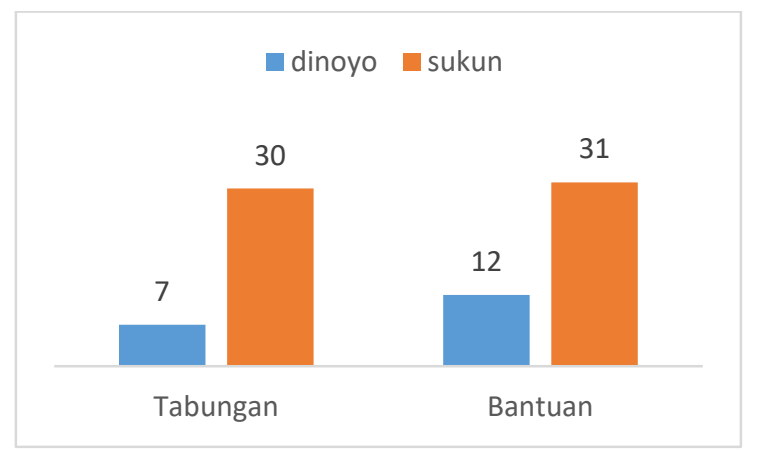

Fig 7 Savings ownership and assistance

\subsection{Physic Capital}

Aspects that are used to calculate the physical capital are the condition of roads and bridges. Good road and bridge conditions will affect the ease of accessibility. Easy access will increase evacuation mobilization when a disaster occurs. The road and bridge conditions in Dinoyo and Sukun Subdistrict are quite good. This is indicated by a value indicating that it is at a value of 2 .

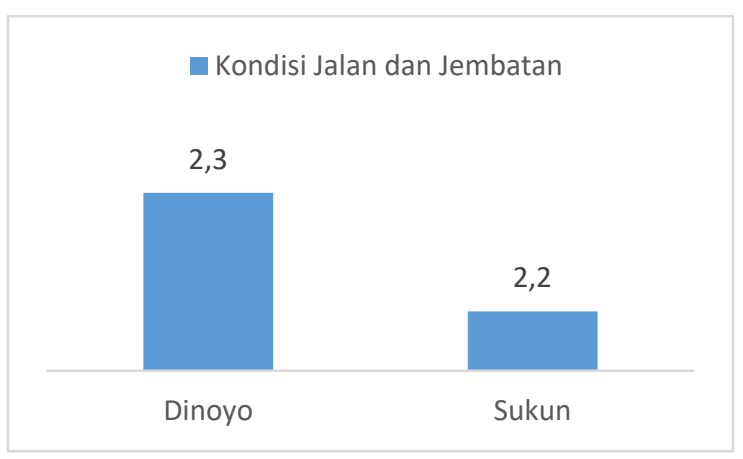

Fig 8 Condition of Road and Bridge

\subsection{Capacity Community Level}

Rated capacity is calculated based on the value of each stock using a composite index. Categories of the low, medium, and high which are composite index results are then translated into scoring form with a value of 1,2 , and 3 . These values are used to create radar charts. Radar diagram is what is known as asset pentagon (Fig 9 and Fig 10)

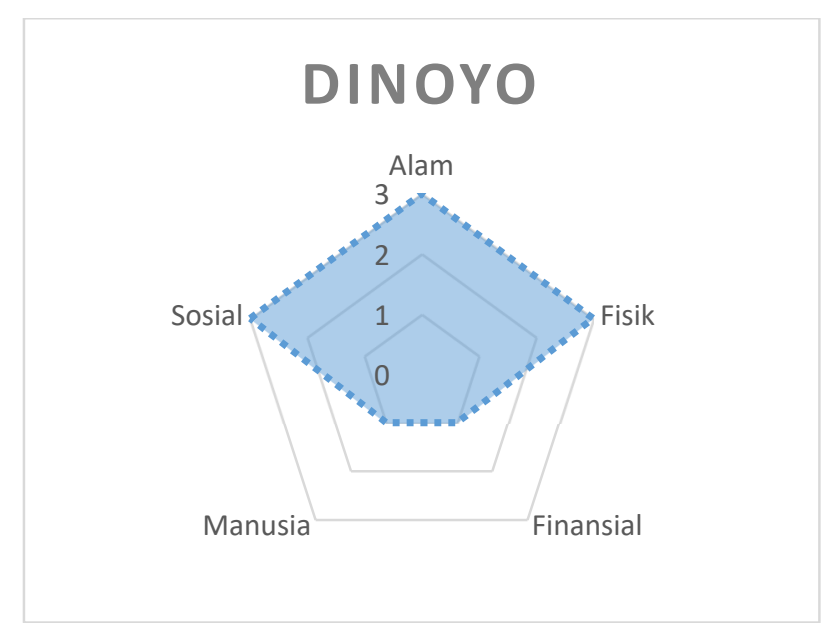

Fig 9 Capacity Communtiy in Dinoyo Subdistrict

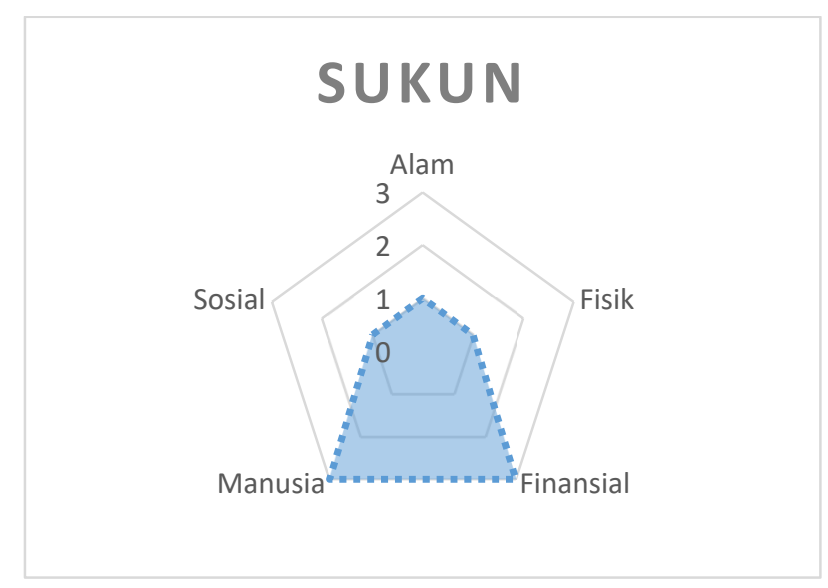

Fig 10 Capacity Communtiy in Sukun Subdistrict 
The illustration results in Fig 9 and Fig 10 show the strengths and weaknesses of the capacities or abilities in the two kelurahan. Dinoyo Kelurahan has excellence in three capacities. These three capacities include Natural, social and physical capital. Meanwhile, the Sukun subdistrict is dominant in human and financial capital.

\section{Conclusion and Recommendation}

\subsection{Conclusion}

The conclusions obtained from the results of the above discussion include:

1 Dinoyo Subdistrict has advantages in social, natural, and physical capacities

2 Sukun Subdistrict has advantages in human and financial capacity

\subsection{Recommendation}

1 Required to increase the scope of the study area if the unit of analysis used was the village.

2 It is hoped that the results of the capacity level can become a reference for calculating disaster risk and disaster needs.

In the preparation of this study, there was support from various parties. Researchers specifically thank LPPM UB, Resilient Subdistrict Residents in Sukun and Dinoyo for taking research respondents, Permits and Facilitation by the Government of
Lowokwaru District, Sukun District, Dinoyo Subdistrict and Sukun Subdistrict, Malang City BPBD, and Malang City Government who are communities which have helped both data and personnel support.

\section{References}

1. Department for International Development, Sustainable Livelihoods Guidance Sheets, Brighton: DFID (1999)

2. International Council of Nurse (ICN) \& World Health Organization (WHO), ICN Framework of Disaster Nursing Competencies, WHO/WPRO. Geneva (2009)

3. A. K. Mizam, The Role of Health Workers in Disaster Management, Husada Media Health Scientific Journal, 1(1) (2012)

4. S. Saragih, J. Lassa, A. Ramli, Sustainable Livelihoods Framework (2007)

5. UN-ISDR (United Nations secretariat of the International Strategy for Disaster Reduction). Living with risk: A global review of disaster reduction initiatives. Geneva: UN Publications (2004)

6. R. Wijayanti, M. Baiquni, R. Harini, Asset-Based Community Sustainable Livelihood Strategy in Pusur Sub-watershed, Bengawan Solo Watershed. Region and Environment, 133-152 (2016) 